\title{
Fogászati allergiás megbetegedések kialakulásában szerepet játszó polimer felületek jellemzése fág bemutatásos technikával
}

\author{
SZALÓKI MELINDA*, RADICS TÜNDE*, HEGEDŰS CSABA*
}

\begin{abstract}
A fogászati kezelések során sokféle anyag kerül felhasználásra, amelyek az arra érzékeny pácienseknél allergiás reakciót válthatnak ki. Ezen immunválasz mögött többlépcsős biokémiai folyamatok állnak, amelynek egyes fehérje kölcsönhatásait irányított evolúciós, fág bemutatásos technikával lehet vizsgálni. Munkánk során a fogsoralapanyagként is használt polisztirol (PS) felületéhez kötődő aminosav szekvenciákat határoztuk meg fág bemutatással. Pozitív kontrollként a polimer felületéhez kötött streptavidin (Str) fehérjét, negatív kontrollként marhaszérum albuminnal blokkolt polisztirolt választottunk. Eredményeink alapján megállapítottuk, hogy a WLFNHPQ szekvencia Str specifikus szekvenciának tekinthető, mivel ez a variáns három független mintában többször előfordult. Az albuminnal blokkolt polisztirol felületéről válogatott fágok néhány variánst tartalmaztak, néhány előfordulással. Jelen munkában bemutattuk, hogy a polisztirol felületéhez kötődnek peptidek, habár ezen termoplasztikus polimerek használata során eddig nem számoltak be allergiáról, ami valószínúleg az alkalmazott technológia eredménye lehet. A leggyakoribbnak a FSGRPLP aminosav szekvencia adódott. Az antigén prezentációban szerepet játszó kötőfelszínek ismerete és blokkolása segít feltérképezni, csökkenteni az allergiás reakciók kialakulását.
\end{abstract}

Kulcsszavak: fág bemutatás, oligopeptid, polisztirol, polimer felületéhez való kötődés

\section{Bevezetés}

A fogászati anyagokkal szemben a szervezetben kialakuló hiperszenzitivitás egy kevéssé vizsgált terület. A fogászati kezeléseknél a pontos allergológiai diagnózisnak nagy jelentősége van, ugyanis a kezelések (pl. a pótlások eltávolítása, új pótlás készítése) nagy financiális terhet jelenthetnek a betegeknek. Nemzetközi felmérések szerint a fogászati allergiás megbetegedések száma évről évre növekszik. Kutatások támasztják alá, hogy a fogászati anyagokkal szemben kialakult allergiás megbetegedések nagy százalékban kombinált formában lépnek fel, amikor is mind a fémekkel, mind a polimerekkel szemben pozitív választ produkál az adott egyén szervezete $[24,28]$. A kombinált formában fellépő allergiás előfordulási gyakoriság a nők körében gyakoribb [27]. A fémek körében leggyakoribb allergének a palládium, nikkel, higany, kobalt [25, 27]. A fogászatban alkalmazott polimerek és bomlástermékeik is okozhatnak allergiát. A fogászati polimerekből izolált leggyakoribb alkotók és bomlástermékek a metil-metakrilát (MMA) [14], 2-hidroxietilmetakrilát (HEMA), trietilénglikol-dimetakrilát (TEGDMA), etilénglikol-dimetakrilát (EGDMA), trimetilolpropán-trimetakrilát (TMPTMA) [6] és a benzoil-peroxid (BPO) [4, 7], bomlástermékként pedig a formaldehid $[4,5,18,26]$ és a metakrilsav $[5,26,32]$ fordult elő. A leggyakoribb allergén a bomlástermékek között a formaldehid [4, 5, 25, 26].
A polimetil-metakrilát (PMMA) és metil-metakrilát rendszerek az 1950-es években jelentek meg a kereskedelemben. Mára a legfontosabb rendszerré nőtték ki magukat a kivehető pótlások alapanyagaként. Egyéb "hipoallergénnek" nevezett anyag is kifejlesztésre került az elmúlt években. Earl W. Renfroe közleményében a polisztirol többirányú fogászati felhasználását mutatta be [10], Charles Dimmer a polisztirolból készült fogsor alaplemezt (Jectron), majd az előállítási technológiát (fröccsöntési módszer) is szabadalmaztatta [13]. A nagy ütésállósággal rendelkező polisztirolt azzal az előnyös tulajdonsággal vezették be, hogy kevesebb vizet vesz fel, mint más egyéb polimerből készült fogsoralaplemez [8, 31].

Nagyon kevés információ van arra vonatkozóan, hogy milyen molekuláris reakciók léphetnek fel pl. az előbbiekben említett anyagok esetében a polimerből kioldódó alkotók, degradációs termékek és a különféle fehérjék között, melyek fontosak az allergiás reakciók kialakulásának folyamatában.

Az allergia a szervezet egyik hiperszenzitivitási reakció mechanizmusa. Az allergia olyan szerzett állapot, amelyben a szervezet túlreagálása történik egy a vele érintkező idegen anyaggal szemben. Az allergiás megbetegedés első fázisában, a szenzibilizációban, az önmagukban nem immunogén haptének ( $\mathrm{pl}$. Ni, benzoilperoxid) kötődnek sejtfelszíni vagy szolubilis fehérjékhez, 
majd az így kialakult allergént (haptén és fehérje komplex) az antigént prezentáló Langerhans-sejtek eljuttatják a nyirokcsomóba, és az itt lévő T-limfociták antigénspecifikus memóriasejtekké alakulnak át. Az említett konjugációs kölcsönhatásokban, a kötőfelszínek kialakításában aminosav kombinációk sokasága vehet részt. A fehérje kölcsönhatások vizsgálhatók, pl. irányított evolúciós technikával. A leggyakoribb irányított evolúciós technika a fág bemutatás (phage display) $[3,15,19]$. Fág bemutatásos technikára többféle bakteriofág alkalmazható. A bakteriofágok baktériumot fertőző vírusok. A fág bemutatásos technika során leggyakrabban használt bakteriofág a fonalas M13 fág [23]. Előnyük, hogy egyszerüen kezelhetők, a fenotípus és a genotípus közötti fizikai kapcsolat könnyen biztosítható, F-pilussal rendelkező baktériumokat fertőznek meg, így ezekben könnyen szaporíthatók [17]. Ezen egyszerű szervezetek egyszálú DNS láncában egy ismert szekvenciájú, kombinatorikus módszerrel előállított heptamer vagy dodekamer peptidet kódoló szakasz található. Ugyanazon peptid szekvencia a fág burokfehérjéjéhez is fuzionálva van, így a fág adott felületre való ráhelyezésekor ezen peptidek kerülnek bemutatásra, amelyek affinitásuknak megfelelően erősebben vagy gyengébben kötődnek. A kötődött fágok amplifikálására, a fág Escherichia coli gazdasejtben szaporítható. Ahhoz, hogy különbséget tegyünk az idegen DNS-t tartalmazó és nem tartalmazó plazmidok között, a színtelen X-gal molekulát alkalmaztuk. A coli gazdasejt fággal történt fertőzés hatására enzim (béta galaktozidáz) termelődik, ami az X-gal molekula szubsztráttal kék színű terméket produkál. A bakteriofággal történt fertőzés hatására termelődő enzim jelenléte vagy hiánya egyszerüen, érzékenyen kimutatható, valamint egy kék színú plakk egyértelmúen egy klónt jelöl a telepen.

Számos fág bemutatásos vizsgálat történt különféle anyagok (fémek, félfémek, kristályos anyagok és poli-

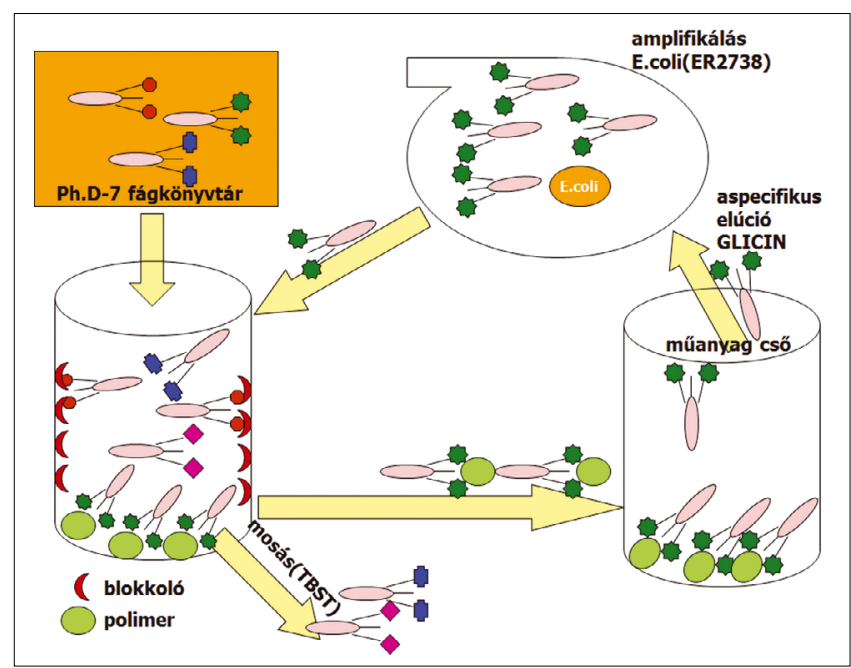

1. ábra: Fág bemutatásos technika lépéseinek szemléltetése Ph.DTM-7 fág könyvtár használatával blokkolt polimer felületen merek) felületén az anyagok felületi sajátosságainak vizsgálatához [21].

Jelen munkánk célja fág bemutatásos technika vizsgálati módszer alkalmazása a modellként is használható polisztirol felületének jellemzésével. A jelenlegi kísérlet eredményei nagymértékben hozzájárulhatnak későbbi munkáinkhoz, amelyekben a fogászatban jelenleg is használt polimerek felületének jellemzését végeznénk el fág bemutatásos módszer használatával. A szintetikus polimerek felületéhez kötődő specifikus és nem specifikus aminosav szekvenciák meghatározása fág bemutatásos módszerrel közelebb vihet azon mintázatok (peptide motif), oligopeptidek megismeréséhez, amelyek részt vehetnek a kötőfelszínek kialakításában, az antigén-prezentációban, illetve az allergiás folyamatok megismerésében.

\section{Vizsgálati anyag és módszer}

A fág bemutatásos technikát a NEB (New England BioLabs Inc. Ipswich, MA) protokollja szerint végeztük el. A fág könyvtárban nagyszámú, egyedi változatot tartalmazó, kombinatorikus peptid, illetve fehérje található (egyedi fágokról 100 másolat fág könyvtár $10 \mu \mathrm{l}-$ ében). Jelen munkánkban az általunk használt 7 tagú fág könytár (Ph. $\mathrm{D}^{\mathrm{TM}}-7$ ) random heptapeptidek kombinációját tartalmazta, ami az M13 fonalas bakteriofág $\mathrm{p}$ VIII burokfehérjéhez egy Gly-Gly-Gly-Ser flexibilis linkeren keresztül kapcsolódik.

Kísérleteinket 96 lyukú polisztirol lemezen (Thermo Immulon $1 \mathrm{~B}^{\circledR}$ közepes kötődésü) végeztük el háromhárom független mintával $(n=3)$. Negatív kontrollként a marhaszérum albumin (BSA) fehérjével blokkolt polisztirolt választottuk. A blokkolással azon peptidek kötődése gátolható, amelyek a polimer felületéhez nagyobb affinitással kötődnének. Pozitív kontroll a polisztirol streptavidin (Str) fehérjével borított felszín volt. A protokoll szerint azoknak a peptideknek, amelyek a Str fehérjéhez kötődnek, a His-Pro-Gln (HPQ) mintázatot kellene tartalmazniuk. A vizsgálandó minta a nem blokkolt, tiszta polisztirol volt.

A fág könyvtárból higításokat $\left(2 \times 10^{11} \mathrm{db}\right.$ fág / könyvtár $2 \times 10^{9}$ klónnal) készítettünk, majd ráhelyeztük a megfelelően előkészített mintákra. A nem kötődő fágokat TBST-vel (Tweent tartalmazó Tris puffer) mostuk le. A kötődő fágokat a polisztirol felületről glicinnel, míg a Str borított felületről a kötődő fágokat a protokoll szerinti biotin TBS-es oldatával eluáltuk. Ezek után az F pilussal rendelkező Escherichia coli gazdasejtben (ER 2738) felszaporítottuk (amplifikáltuk) (1. ábra).

Ezt a szelekciós kört egymás után háromszor végeztük el úgy, hogy az első körből tisztított, amplifikált fágokat újra, a megfelelően előkészített (Str kezelt, BSA blokkolt és nem kezelt) felületekre helyeztük. A harmadik szelekciós kör végén kapott eluált fágok hígításait a felnövesztett Escherichia coli gazdasejttel együtt LB/ IPTG/X-gal táptalajjal ellátott lemezekre öntöttük, majd 
hagytuk felnőni a kék színú plakkok megjelenéséig $\left(37^{\circ} \mathrm{C}\right.$, egy éjszaka). A plakkok egyenként egy-egy klónt jelentettek, amelyekből random módon 20-20 darabot kiválasztottunk. A kiválasztott klónokat egyenként amplifikáltuk, majd az Escherichia colitól való tisztítás után kinyertük a fág DNS-ét. A DNS kinyerése és tisztítása $\mathrm{Nal} /$ etanolos kicsapással történt, majd az egyszálú DNS-ek koncentrációját nanodroppal (NanoDrop 1000, Thermo Scientific, USA) mértük meg. A kötőképes klónok által hordozott gének bázis sorrendjének meghatározása -96 glll szekvenáló primer használatával történt (Macrogen Europe, Amsterdam, Hollandia).

A peptidekben az aminosavak előfordulási gyakoriságának és hidrofilicitás szempontbeli meghatározására Mega6 programot használtunk.

\section{Eredmények}

Peptid szekvenciák pozitív, negatív kontroll és polisztirol vizsgált felületen

A Str-polisztirol (Str-PS) felületéhez, a marhaszérum albuminnal blokkolt polisztirolhoz (BSA-PS) és a kezeletlen felszínú polisztirol mintához kötődő fágok által hordozott leggyakoribb aminosav szekvenciákat az 1. táblázatban összegeztük.

1. táblázat

Pozitív kontroll (Str-PS felület), negatív kontroll (BSA-PS) és polisztirol felületekról eluált leggyakoribb peptid szekvenciák. Az egyes szekvenciák mögé zárójelbe írt számok jelölik a gyakoriságot.

\begin{tabular}{|c|c|c|}
\hline $\begin{array}{c}\text { Streptavidinnel borított } \\
\text { PS felületen } \\
\text { (pozitív kontroll) }\end{array}$ & $\begin{array}{c}\text { Marha szérum } \\
\text { albuminnal blokkolt } \\
\text { PS felületen } \\
\text { (negatív kontroll) }\end{array}$ & PS felületen \\
\hline GLFNHPQ (3) & AGAYVAT (2) & DNKAIIN (2) \\
\hline WLFNHPQ (8) & DVYSFSV (2) & FSGRPLP (8) \\
\hline GWFNHPQ (2) & FARYMGD (2) & QRHMSSI (2) \\
\hline & FSRTLPT (2) & VSRDTPQ (3) \\
\hline & FSTTHPD (3) & \\
\hline & FTRTIHT (2) & \\
\hline & GTSTTAQ (3) & \\
\hline & HASNAGA (3) & \\
\hline & HSHTLTW (2) & \\
\hline & IKSVTDW (2) & \\
\hline & SIYGLAE (2) & \\
\hline & TTLGVWT (4) & \\
\hline & VGSYLGI (3) & \\
\hline
\end{tabular}

A streptavidinnel borított felületen a WLFNHPQ szekvencia fordult elő a legnagyobb gyakorissággal. A Str-PS felületről eluált fágokban a konszenzus mintázat a $\mathrm{HPQ}$ tripeptid, a NEB protokolljának megfelelően. A BSA-PS felületről eluált peptidekben több konszenzus mintázat jelent meg. A legfelismerhetőbbek az FXRT, FSXT tet- rapeptidek, ahol $\mathrm{X}$ bármilyen aminosavat jelöl. A polisztirol felületen a FSGRPLP szekvencia fordult elő a legnagyobb gyakorisággal.

\section{Peptid szekvenciák jellemzése}

polisztirol felületen

A módosított polisztirol (Str-PS és BSA-PS) és a kezeletlen polisztirol felületen válogatott oligopeptidekben az aminosavak oldallánc jellege szerinti csoportosítást a 2. ábra mutatja. Az apoláros oldalláncú aminosavak a legnagyobb számban fordulnak elő mindhárom felületen. A BSA-val blokkolt és kezeletlen PS felületen az apoláros oldalláncú aminosavak közel egyforma gyakorisággal fordultak elő. A poláros oldalláncú aminosavak a BSA-val blokkolt felületen mutattak nagyobb gyakoriságot. A BSA-val blokkolt felületen 38,39\%, míg a natív $P S$ felületen $25,71 \%$ volt a poláros jellegú aminosavak megoszlása a legnagyobb gyakorisággal eluált fágokban.

A savas és a bázikus (elektromosan töltött) oldallánccal rendelkező aminosavak elmaradnak az apoláros és poláros csoportoktól. Savas jellegú aminosavak a pozitív kontroll esetében nem voltak. A bázikus karakterü aminosavak a kezeletlen PS esetében mutattak legnagyobb gyakoriságot.

\section{Megbeszélés}

A fogászatban alkalmazott fág bemutatás (phage display) technika lehetőséget ad azon oligopeptidek megismerésére, amelyek nagy affinitással kötődnek a polimerek vagy fémek felületéhez, segítve ezzel az allergia patomechanizmusának, elsősorban az antigén prezentációnak a megértését. Polimer felületen több kutatócsoport végzett fág bemutatásos technikát.

Munkánk során polisztirol felületén végeztük el a fág bemutatásos technikát, azzal a céllal, hogy megismerjük azokat a gyakori szekvenciákat, amelyek a legnagyobb affinitással kötődnek a hidrofób polimer felületéhez a kombinatorikus egyedi változatokat tartalmazó kiindulási fág könyvtárból. Pozitív kontrollként a PS felületéhez kötött streptavidin célmolekulát választottunk. Az irodalomból ismert, hogy a legfelismerhetőbb tripeptid mintázat (HPQ) ugyanazon kötődési helyen kötődik, mint a biotin. Az álalunk elvégzett kísérleti eredményekben is megfigyelhető volt a HPQ mintázat a streptavidinnel borított polimer felületen (1. táblázat). $\mathrm{A} \mathrm{HPQ}$ mintázat a streptavidinkötő peptidek között ismert, de ezen mintázaton kívül is azonosíthatók olyan peptidek, amelyek a streptavidinhez kötődnek [17, 28]. Az irodalomban találtakkal összhangban [30] kísérleteinkben mi is találtunk olyan mintázatot, amely nem felétlenül csak a HPQ mintázatot tartalmazta. Egy másik, legfelismerhetőbb mintázat, a GXFN (X bármilyen aminosavat jelölhet) is elöfordult a HPQ mellett (1. táblázat), amely hasonlít a $\mathrm{GD}(\mathrm{F} / \mathrm{W}) \mathrm{XF}$ mintázathoz, amelyet Roberts és munkatársai találtak hasonló felületen [20]. 


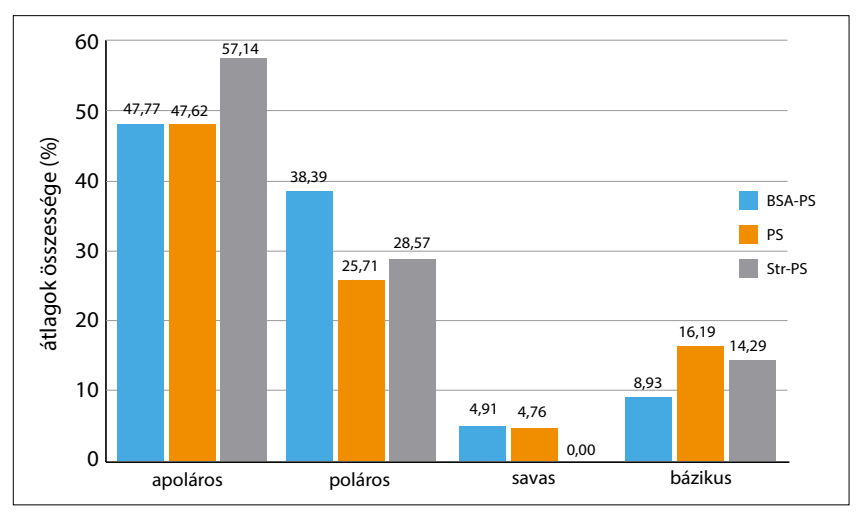

2. ábra: Aminosavak megoszlása jelleg szerint pozitív kontroll (Str-PS), negatív kontroll (BSA-PS) és polisztirol (PS) felületen

a leggyakoribb oligopeptidben megvizsgálva

Negatív kontrollként a marhaszérum albuminnal blokkolt polisztirol felületet választottuk. Az albumin gyakran alkalmazott blokkoló ágens többek között a fág bemutatásos technikában. Ehhez a fehérjéhez gyengén kötődnek különféle hatóanyagok, zsírsavak, hormonok és fémionok. A BSA-kötő ligandum nélkül nem képes specifikusan kötődni a polimer felületéhez. Több kutató a BSA fehérjét specifikus funkciós csoporttal látta el a fág bemutatásos vizsgálat elvégzéséhez [30]. A BSA egy vízben jól oldódó, monomer globuláris fehérje, ami blokkoló ágensként való használata során a polisztirol felületén hidrát burokkal van borítva. A felületi hidrát burok következménye lehet annak, hogy a BSA-blokkolt PS felületen több poláros oldalláncú aminosav kötődik (2. ábra), mint az apoláros jellegű, kezeletlen polisztirol felületen. A fehérje felületén lévő vízmolekulák elmozdításához, vagyis a kötődés kialakulásához bizonyos mértékű potenciális kötődési energiára van szükség. Ez az energia a kisméretű peptid ligandokban gátként jelentkezhet [30]. A szakirodalomban több szekvenciát is találunk, amelyek a marhaszérum albuminhoz kötődnek. Ezek a BSA-kötő szekvenciák eléggé változatos képet mutatnak, ami az előzőekben leírtakat igazolja. Abban az esetben, ha a szelekciós kört úgy végezzük el, hogy a peptidek számára nincs irányított, vagy erős csatlakozási pont a felületen, akkor az albumin tekinthető olyan felületnek, amelyhez a peptidek nagy valószínüséggel kötődnek. Az általunk elvégzett kísérlet is ezt támasztja alá. A BSA-val blokkolt felületen többféle variáns kisebb gyakorisággal rendelkező változatait (1. táblázat) izoláltuk. A bemutatott eredmények alapján a blokkolt PS felületén leggyakoribb heptapeptidekben a FXRT, FSXT legfelismerhetőbb konszenzus mintázatokat találtuk (1. táblázat), ahol $X$ bármilyen aminosavat jelöl.

Egy polimer felülethez gyakorlatilag az összes peptid kötődik valamilyen mértékben, miközben az abszorbeált proteinek részlegesen denaturálódnak a felületen [11]. Lesznek olyan peptidek, amelyek erősebben kötődnek, így a mosási lépésekben ezek nem moshatók le, így a körök számának növekedésével felszaporodnak. A polisztirol felületén elég sokféle peptidet sikerült azonosítani más kutatócsoportoknak [30, 9]. A hidrofób polisztirol felületén elsőként Adey és munkatársai vizsgálódtak, és azt találták, hogy WXXW mintázatú peptidek kötődnek a hidrofób polisztirol felülethez, ahol $X$ bármilyen aminosav lehet [1, 12]. Anni és munkatársai hasonló eredményre jutottak a módosított BSA-val borított polisztirol felületen, ahol a FHENWPS (Phe-His-Glu-AsnTrp-Pro-Ser) klónt izolálták [2]. A NEB (New England Biolabs) munkatársai a FHWTWYW (Phe-His-Trp-ThrTrp-Typ-Trp) szekvenciájú klónt igazolták a polisztirol felületén és megállapították, hogy a polimer felületén tipikusan aromás aminosavakban gazdag (tirozin, triptofán és fenil-alanin) oligopeptidek és ezek változatai kötődnek [33]. Vodnik és munkatársai célmolekula független, polisztirol felületéhez kötődő peptidet igazoltak HWGMWSY (His-Trp-Gly-Met-Tpr-Ser-Tyr) szekvenciával [29]. A szerzők leírják, hogy a különböző munkacsoportok által végzett fág bemutatásos módszer a polisztirol felületén eredményezhet hasonló klónokat, de nem egyezik meg az általuk talált HWGMWSY szekvenciával. Ezt a szekvenciát tartják célmolekula független, polisztirolhoz kötődő oligopeptidként számon. Menendez és munkatársai táblázatosan mutatják be, milyen konszenzus polimerkötő mintázatok találhatók a szakirodalomban [16]. A WXXW, WXXWXXXW és az FHXXW mintázatok mellett voltak olyanok, amelyekben felismerhető konszenzusmintázat nem volt. A PS felületén a Phe-Ser-Gly-Arg-Pro-Leu-Pro (FSGRPLP) szekvenciát izoláltuk a legnagyobb számban három szelekciós kör után. A polisztirol aromás gyürúi könnyen polarizálható delokalizált elektronokat tartalmaznak, így indukált dipólus kölcsönhatásokban vehetnek részt. A más kutatók által leírt polisztirol specifikus szekvenciákban fenilalanin (Phe, F) aminosavakban gazdag oligopeptidek gyakoriak. A fenil-alanin aromás gyűrüje és a polisztiol aromás gyürüje között alakulhat ki indukált-indukált másodrendú kölcsönhatás $(\pi-\pi)$, ami lehet a random fág könyvtárból való szelektivitás mozgatója. Az általunk talált oligopeptidek között is voltak olyan ismétlődő szekvenciák, melyeknek végállása fenil-alanint tartalmazott.

A szakirodalomban található PS specifikus peptidekben a variánsok széles skálán mozognak. Ennek hátterében a különböző polisztirol felületek, és eltérő kiindulási fág könyvtárak használata, célmolekula független kötődéses vizsgálat és a módszer kombinatorikus jellege is állhat.

A peptid szekvenciákat aminosavak alkotják, amelyeknek oldalláncai, funkciós csoportjai befolyásolják a peptidek jellegét és a felülethez való viszonyát. A fág könyvtárból valamilyen irányba történő feldúsulás kapcsolatban van a peptid és a felület jellegével. Serizawa és munkatársai szindiotaktikus (monomer egységenként szabályosan változó) PS felületen végeztek fág bemutatásos módszert, amelyben a YLTMPTP szekvenciát találták, amellyel bemutatták, hogy a peptidek felismerik a polimer felület sztereoregularitását [22]. 
A polisztirol specifikus peptidek apoláros (hidrofób) vagy aromás aminosavakban gazdag peptidek [1, 33]. Az általunk talált polisztirol specifikus szekvenciák is apoláros (hidrofób) oldalláncú aminosavakban gazdag oligopeptidek (2. ábra).

Jelen munkában bemutattuk, hogy a polisztirol rugalmas fogsoranyaghoz is kötődnek peptid szekvenciák. Felhasználásuk során eddig nem számoltak be allergiás megbetegedésről. Ennek hátterében az állhat, hogy ezen pótlások fröccsöntéssel készülnek, amelyek elkészítéséhez kész polimereket használnak. Ezeknek a termoplasztikus polimereknek a szabad monomer tartalma elhanyagolható, ellentétben a polimetil-metakrilát bázisú termoszet polimerekkel. A PMMA bázisú rendszerek felhasználása során a polimerizált metilmetakrilátot, metil-metakrilát monomerrel keverik öszsze. A rendszerben maradó el nem reagált monomerek, azok bomlástermékei (metakrilsav, formaldehid) és polimer alkotói (kisebb fragmentumok, benzoil-peroxid iniciátor) okozhatnak hiperszenzitivitási reakciót arra érzékeny páciens esetében. Összességében megállapítható, hogy a polisztirol felületen apoláros oldallánccal rendelkező aminosavakban gazdag peptidek kötődnek nagyobb affinitással. A FSGRPLP szekvenciát találtuk a legnagyobb gyakorisággal az általunk használt polisztirol felületen. A későbbiekben a jelen munkában elvégzett vizsgálataink alapján más, a fogászatban régóta (polimetil-metakrilát rendszerek), illetve újszerűen használt polimeren (3D nyomtatáshoz használt polimereken) fág bemutatásos technikával kívánjuk meghatározni azokat az oligopeptideket, amelyek nagy affinitással kötődnek az ilyen jellegű felszínekhez. Az antigén prezentációban szerepet játszó felületi kötőhelyek ismerete és azok blokkolása segíthet az esetlegesen kialakuló allergiás reakciók gyakoriságának csökkentésében.

\section{Köszönetnyilvánítás}

A kutatás a TÁMOP 4.2.4.A/2-11-1-2012-0001 azonosító számú Nemzeti Kiválóság Program-Hazai hallgatói, illetve kutatói személyi támogatást biztosító rendszer kidolgozása és működtetése országos program címú kiemelt projekt keretében zajlott. A projekt az Európai Unió támogatásával, az Európai Szociális Alap társfinanszírozásával valósul meg.

\section{Irodalom}

1. AdEY NB et AL: Characterization of Phage That Bind Plastic from Phage-Displayed Random Peptide Libraries. Gene 1995: 27-31.

2. Anni H, Nikolaeva O, Israel Y: Selection of Phage-Display Library Peptides Recognizing Ethanol Targets on Proteins. Alcohol 2001: 201-209.

3. AzZazy HM, Highsmith WE, JR: Phage Display Technology: Clinical Applications and Recent Innovations. Clin Biochem 2002: 425-445.

4. BaKó, J, Kelemen M, Hegedús Cs: Analysis of benzoyl-peroxide and formaldehyde as dental allergens by FT-SPR method. IOP Conf. Ser.: Mater. Sci. Eng 2013: 012001
5. BaKó J, Kelemen M, Szalókı M: Fogsor alaplemezből kioldódó allergének kötődésének vizsgálata Fourier-Transzformációs Felületi Plazmon Rezonancia (FT-SPR) módszerrel. Fogorv Szle 2015: 13-18.

6. Bettencourt AF et al: Biodegradation of Acrylic Based Resins: A Review. Dent Mater 2010: 171-180.

7. BoeCKLER AF et AL: Release of Dibenzoyl Peroxide from Polymethyl Methacrylate Denture Base Resins: An in Vitro Evaluation. Dent Mater 2008: 1602-1607.

8. Brauer GM: Dental applications of polymers: a review. J Am Dent Assoc 1966: 1151-1158.

9. Desjobert $C$ et al: Identification by Phage Display Selection of a Short Peptide Able to Inhibit Only the Strand Transfer Reaction Catalyzed by Human Immunodeficiency Virus Type 1 Integrase. Biochemistry 2004: 13097-13105.

10. EarL W Renfroe: Rapid Fabrication of Plastic Retainers. The Angle Orthodontist: January 1947: 34-40.

11. Filisko FE, Malladi D, Barenberg S: Character of Adsorbed Bovine Serum-Albumin from Adsorption Enthalpies. Biomaterials 1986: 348-353.

12. Gebhardt K et AL: Adhesive Peptides Selected by Phage Display: Characterization, Applications and Similarities with Fibrinogen. Pept Res 1996: 269-278.

13. Khindria SK, Sanjeev Mittal, Urvashi SukHiJa: Evolution of denture base materials. The J Indian Prosth Soc 2009: 64-69.

14. Kopperud HM, KLeven IS, Wellendorf H: Identification and Quantification of Leachable Substances from Polymer-Based Orthodontic Base-Plate Materials. Eur J Orthod 2011: 26-31.

15. Liu R, Enstrom AM, Lam KS: Combinatorial Peptide Library Methods for Immunobiology Research. Exp Hematol 2003: 11-30.

16. Menendez A, Scott J K: The Nature of Target-Unrelated Peptides Recovered in the Screening of Phage-Displayed Random Peptide Libraries with Antibodies. Analytical Biochemistry 2005: 145-157.

17. Mohan K, WeISS GA: Dual Genetically Encoded Phage-Displayed Ligands. Anal Biochem 2014: 1-3.

18. Oysaed H, RuYter IE, SJoviK KLeVen IJ: Release of Formaldehyde from Dental Composites. J Dent Res 1988: 1289-1294.

19. Pande J, Szewczyk MM, Grover AK: Phage Display: Concept, Innovations, Applications and Future. Biotechnol Adv 2010: 849858.

20. Roberts D, Guegler K, Winter J: Antibody as a Surrogate Receptor in the Screening of a Phage Display Library. Gene 1993: 67-69.

21. Seker UO, Demir HV: Material Binding Peptides for Nanotechnology. Molecules 2011: 1426-1451.

22. Serizawa T, Techawanitchai P, Matsuno H: Isolation of Peptides That Can Recognize Syndiotactic Polystyrene. Chembiochem 2007: 989-993.

23. SIDHu SS: Engineering M13 for Phage Display. Biomol Eng 2001: 57-63.

24. Stenman E, Bergman M: Hypersensitivity Reactions to Dental Materials in a Referred Group of Patients. Scand J Dent Res 1989: 76-83.

25. Syed M, Chopra R, Sachdev V: Allergic Reactions to Dental Materials-a Systematic Review. J Clin Diagn Res 2015: ZE04-9.

26. Szalókı M, Vitályos G, HÁrsfalvi J: Binding of leachable components of polymethyl methacrylate (PMMA) and peptide on modified SPR chip. IOP Conf. Ser.: Mater. Sci. Eng 2013: 012002.

27. SzEPESI M és mTSAI: Fogászati anyagokkal szemben kialakuló allergiás megbetegedések és ellátásuk hatékonyságának vizsgálata az észak-alföldi régióban. Fogorv Szle 2014: 135-139.

28. Torgerson RR et AL: Contact Allergy in Oral Disease. J Am Acad Dermatol 2007: 315-321.

29. VodNIK M, StrukelJ B, LUNDER M: HWGMWSY, an Unanticipated Polystyrene Binding Peptide from Random Phage Display Libraries. Anal Biochem 2012: 83-86.

30. VoDNIK M et AL: Phage Display: Selecting Straws Instead of a Needle from a Haystack. Molecules 2011: 790-817. 
31. Woelfel JB, Paffenbarger GC, Sweeney WT: Some physical properties of Organic Denture Base Materials. J Am Dent Assoc 1963: 499-504.

32. Yap AU, Lee HK, Sabapathy R: Release of Methacrylic Acid from Dental Composites. Dent Mater 2000: 172-179.
33. www.neb.com/faqs/2012/09/25/when-performing-an-experimentusing-ph-d-trade-phage-display-the-elisa-indicates-that-background (2016.02.29.)

\section{Szalóki M, Radics T, Hegedüs Cs}

\section{Characterization of dental allergy associated polymer surfaces by phage display technique}

Many materials are used during a dental treatment, which can cause dental allergy in susceptible patients. Behind the immune response there are multistage biochemical processes, in which protein interactions can be investigated by directed evolutionary, phage display technique. Aim of this study is to determine the frequent amino acid sequences on polystyrene surface as dental base thermoplastic polymers by phage display technique. Positive control was streptavidin (Str) covered polymer, the negative control was bovine serum albumin blocked polystyrene. Based on our results it was found that the WLFNHPQ sequence is Str specific peptide in our system, because this variant has occurred repeatedly in three independent samples. The selected phages from the BSA blocked PS surface have contained some variants with some frequency. We demonstrated that peptides bond to PS surface. The most frequent peptide was FSGRPLP on untreated polystyrene surface. However allergy is not reported with the application of PS thermoplastic polymer. The reason of this can be the result of the applied technology, namely the injection moulded technique. In the antigen presentation the knowledge and blocking of the binding sites can help to discover and reduce the formation of allergic reactions. Based on our experiments it can be declared that our PS model system can be a good starting point in the recognition of other dental polymer peptide biding sites.

Keywords: phage display, oligopeptide, polystyrene, binding to polymer surface 